ÉGYPTE

monde arabe

\section{Égypte/Monde arabe}

10 | 2013

Les élections de la révolution (2011-2012)

\title{
Political Representation and Legitimacy in Egypt: The Making and the Reception of Claims during the Parliamentary Elections 2011
}

\section{Sarah Wessel}

\section{(2) OpenEdition \\ Journals}

Electronic version

URL: https://journals.openedition.org/ema/3089

DOI: $10.4000 /$ ema.3089

ISSN: 2090-7273

\section{Publisher}

CEDEJ - Centre d'études et de documentation économiques juridiques et sociales

\section{Printed version}

Number of pages: $37-55$

ISBN: 978-2-905838-81-0

ISSN: $1110-5097$

\section{Electronic reference}

Sarah Wessel, "Political Representation and Legitimacy in Egypt: The Making and the Reception of Claims during the Parliamentary Elections 2011", Égypte/Monde arabe [Online], 10 | 2013, Online since 19 December 2013, connection on 07 July 2022. URL: http://journals.openedition.org/ema/3089 ; DOI: https://doi.org/10.4000/ema.3089

This text was automatically generated on 7 July 2022.

All rights reserved 


\title{
Political Representation and Legitimacy in Egypt: The Making and the Reception of Claims during the Parliamentary Elections 2011
}

\author{
Sarah Wessel
}

\section{Introduction: The Legitimate, Illegitimate Parliamentary Elections ${ }^{1}$}

1 On $1^{\text {st }}$ of October 2011 , seven weeks before the parliamentary elections, the military chief of staff, Sami Enan, met members of the Democratic Coalition ${ }^{2}$. The meeting was held hours after scuffles broke out in Tahrir Square. The outcome was an agreement on a new election law to allow political parties to field candidates in the one-third of seats that had previously been reserved for independent candidates ${ }^{3}$. This agreement was welcomed by many political parties and other groups ${ }^{4},{ }^{5},{ }^{6}$. On 21 st of January the results of the parliamentary elections were announced and the Carter Centre stated after its election witnessing mission: “(...) the results appear to be a broadly accurate expression of the will of the voters"' Nevertheless a few days after the first gathering of the newly elected parliament, thousands of Egyptians were demonstrating in front of the Television Towers of Maspero and on Midan Tahrir. The following slogans were chanted over and over again: "If here is someone from the Muslim Brotherhood, then he should leave right now. We do not want you here". The parliament operated for a few months only: On the 14th of June 2012, the Supreme Constitutional Court (SCC) ruled that the amendments to the election law were not legal. The Supreme Council of the Armed Forces (SCAF) dissolved the parliament and assumed the responsibilities until a new one is elected ${ }^{8}$. Many considered this as a Military soft coup ${ }^{9}$. To date (March 2013) a replacement parliament is yet to be elected. 
2 These related scenarios are difficult to explain with most theories that deal with political representation: Theories on political representation usually focus on elections to explain the legitimacy of representatives by equating political representation with democratic representation ${ }^{10}$. Elections are here usually understood as a kind of ritual, which creates the legitimacy of the representatives and reproduces democracy. Taking this equation for granted, the explanation for the given scenario could be that Egypt is in a transformation process in which procedures like the elections can be free and fair and therefore legitimate, but that authoritarian power relations, structures and institutions are still in existence and too influential to have a "real democracy". At the first glance, this might not be wrong to state. However, this explanation assumes that democratic and authoritarian structures are two independent "systems" that are divided and competing, but not interrelated.

3 Starting from the assumption, that legitimacy is the product of the static facts of elections, the complex changes and interlinked developments concerning political representation and legitimacy cannot be explained. Like the initially given scenario indicates, in times of transformation, in which the constitution is contested, in which elections might not be considered as being representative, in which institutions as the High Court are considered from many Egyptians as being from the "old regime" and therefore not legitimate - the construction or the making of representation and even the making of legitimacy is much more controversial and dynamic.

4 In this paper I will argue, that we have to overcome the implicit division between "democratic" and "authoritarian systems" in order to analyse the controversial and dynamic construction of representation and the making of legitimacy in Egypt in a period of transformation. Therefore I will first present a theory on political representation, which focuses on the practices of politics and is more empirical driven instead of using a normative approach ${ }^{11}$. Consequently, I will show how legitimacy is negotiated and renegotiated during the parliamentary elections 2011/2012 in Egypt. On the one hand I hope to contribute to the new theoretical approaches on political representation by trying to adapt them. I also try to make sense of different interrelated events and scenarios during the parliamentary elections and the transformation process in Egypt in general, that often seem confusing at a first glance. On the other hand I hope to foster a discussion about normative driven theories and their impacts: Approaching legitimate political representation from an empirical point of view might enable a more dense analysis of political practices and shed light on more subtle authoritarian structures and decision-making processes that are also part of every democracy.

\section{Political Representation, Legitimacy and Claims}

5 Michael Saward looks at political representation through the lens of representative claims $^{12}$. Like Nancy Schwartz ${ }^{13}$ or Andrew Rehfeld, he approaches legitimate political representation from an empirical perspective. Rehfeld argues: "political representation has a robust non-normative descriptive sense, that is, it describes facts about the political world without necessarily appealing to normative standards of legitimacy or justice" ${ }^{14}$.

6 Saward understands political representation as a multisided process of claim-making and the reception and the judgment of the claims ${ }^{15}$. Starting from this approach, 
democratic elections can only be considered as a snap shot that shows the acceptance of certain claims at a certain moment. The process of making claims and receiving claims starts before the elections and continues after the elections. This approach stresses a new way of looking at political representation with a focus on the interplays and reciprocal effects between different actors or groups - on the ways would - be representatives make their claims, how they frame them, and how these claims are received and accepted. Consequently, legitimacy is here understood as acceptance of people and groups, which is changing over time and can be institutionalized in different ways, depending on current conditions ${ }^{16}$.

Using this approach raises the following questions: How are claims made and received before, during and in the aftermath of elections? From which groups of people are they accepted or rejected and why? What are the interplays and reciprocal effects between the claim-making and the claim-receiving? Where can we identify ruptures/changes or even contradictions of claim-making and claim-receiving? How can these be explained?

In order to answer these questions I will focus on the claim-making and claim-receiving of the four coalitions that were established during the election process in Egypt: The Democratic Alliance (led by the Freedom and Justice Party from the Muslim Brotherhood), the Egyptian Bloc (led by the Party of the Free Egyptians, the Islamic Coalition (led by the Party of Light from the Salafis) and the Alliance to Complete the Revolution (led by the Social Alliance Party) ${ }^{17}$.

\section{Claim-Making Strategies of Parties and Claim- Receiving}

9 It is obvious that financial resources and the organizational structure of parties play a crucial role to bring the claims to the public, to get access to a broad audience. The four coalitions were led by the parties with the biggest amount of financial resources and therefore had better chances to win more seats in the elections ${ }^{18}$. The financial and organizational discrepancy between the coalitions was immense. This discrepancy was also reflected in the streets: While the Democratic Alliance with the Freedom and Justice Party strongly dominated the streets in Cairo with its banners and posters, the Alliance of Completing the Revolution hardly could afford to hang up banners and posters, probably also due to the lack in their organizational structure. The Party of the Free Egyptians, which was founded by the billionaire Naguib Sawiris ${ }^{19}$ instead, was one of the first that started their election campaign by putting huge advertisings at exposed sites as skyscrapers and highways ${ }^{20}$.

Besides the financial and organizational sources that enable the parties and enhances their possibilities to bring their claims forward, the question of how the parties render their claims is crucial to understand how the impression of presence was created. I will give now three examples of the reciprocity between claim-making and claim-receiving that are embedded in certain discourses and frames: The revolution frame, the religion frame and the discourse about legitimacy itself, elaborating on the scenario given in the introduction. 


\section{The Revolution-Frame: Catch the fulul}

11 Since January 2011 the "revolution" became a constant, which was used as benchmark to assess would-be representatives. During the parliamentary election every candidate who claimed to be a future legitimate representative therefore had to refer somehow to the revolution and how he/she was participating in it. Someone, who was in the old system of Mubarak, had to explain how he or she supported the revolution much more than someone, who was not in the old system, in order to show that he is following new ideas that are associated with the revolution. Different campaigns against the fulul, the so-called remnants of the old regime, appeared. Youth movements spread lists with names of the fulul and started the initiative "Catch the fulul"21.

Consequently, the history of a party and its members and which role they played in the past and during the political upheavals was strongly shaping their claims. While the earlier opposition parties, like the Wafd Party, were considered from most of my informants as part of the regime while the religious parties, the Party of Light and the Freedom and Justice Party, my informants referred to as the Muslim Brotherhood and the Salafis, were mainly considered as the real opposition to the "Mubarak-system".

For the liberal parties it seemed to be much more difficult to gain acceptance from the people - even when they were not considered as fulul - for mainly three reasons: (1) The concept of liberalism was not easy to understand, (2) the names of the parties sounded very similar, what confused people, and (3) they did not have a past as a "real" opposition during Mubarak time in the eyes of many people. This was one of the main reasons, why they built their campaigns around famous figures in Egypt that are well known for a long time and had a past as Naguib Sawiris, Anwar Sadat, Muhammad alSawy, Amr Hamzawy. Anwar Sadat stated: “The people do not care very much about programs. People are more interested in persons than in political parties. People vote the people they know. This is why I am promoting my name and my party is behind me"22. This also explains why the liberal parties, although they had almost all a similar program did not make one big party: they were depending on creating a past through famous individuals that could be considered as anti-fulul ${ }^{23}$.

14 The discourse about fulul deeply influenced the procedures of the elections. It was mainly due to the fear that former members of the resolved National Democratic Party could win many votes of the one-third of seats that had been reserved for independent candidates that led to the negotiations of the political parties with the SCAF and to the amendments of the election law as mentioned above ${ }^{24},{ }^{25}$. The parties and several activists hoped that the amendments would lower the chances of the fulul to win seats in the elections ${ }^{26}$. To summarize: Only because the discourse about the fulul was so present and strong amongst the population, it could be used to legitimize claims that finally changed the election law.

\section{The Religious Frame: When acceptance becomes visible}

15 A first turning point considering religious discourses was $29^{\text {th }}$ of July when demonstration on Midan Tahrir started, in which mainly supporters of the Muslim Brotherhood and the Salafis participated, while secular political groups and movements disappeared ${ }^{27}$. The collective(s) had been there before, but it was the first time that it raised a claim in the public. It made the religious movements and 
supporters visible and it became clear, that they would play an important role in politics. Many people were completely surprised by the big amount of Muslim Brotherhood and especially Salafi supporters. Ayman, 30, who accompanied me to the demonstrations turned out to be completely surprised by the huge number of Salafis we recognized there around 3 pm. "I was not aware that we have Salafis in Egypt at all, and now look at this", he said ${ }^{28}$. We were standing in front of a stage, where some few members of secular groups, that had decided to stay on Tahrir, held the Koran in the air, to show the approaching group of Salafis, that also for them Islam and religion is meaningful. The big group of Salafis shouted "Islamiya, Islamiya", meaning that they want an Islamic State. The atmosphere became more and more tense. The last few members of the secular groups decided to leave. We left Tahrir and realized dozens of busses around Tahrir, in which mainly Salafis were sleeping inside. Ayman explained to me that the busses brought the demonstrators from the villages and other cities to Tahrir, what indicates that they were very well organized.

Until this day the narrative of a secular and liberal youth revolution was prevalent ${ }^{29}$. Since the demonstrations the presented discourses in the media and the statements of my interview partners changed: The question of the role of Islam within a democracy increased tremendously. Many of my interview partners stated that they have to think anew about the role of the Islam in politics. Some of them, who were in favour of an islamistic state started to question this idea, since they realized that there might be religious political groups, that were too extreme from their point of view, but could be a crucial force in shaping the changing state institutions and structures.

A second turning point was the demonstrations on Maspero of mainly Coptic people that were violently turned down on 9th of October. They stipulated the discussion about the relation between Muslims and Christians in Egypt. The day of Maspero, Mustafa (30) and Sherif (35) went with me to the Tahrir Lounge, a cultural centre close to Midan Tahrir and around half a mile away from the Television buildings of Maspero to a presentation from the Costa Salafi, the youth group of the Salafis. During the presentation we heard loud noises from outside and we got instructions that on our way home we should avoid the 6th of October bridge, because they were violent demonstrations in front of the Television building. We left around $10 \mathrm{pm}$ and asked people what had happened. We got involved in several discussions, mainly with men between 30 and 40. In all the discussions the men said: There are Christians demonstrating at Maspero. There is gunfire and violence. What do they want? We always lived together and there were never problems between Muslims and Christians ${ }^{30}$.

The discourses on the relation between Muslims and Christians and the role of Islam in politics were reflected in the election campaigns from the parties. Many parties framed their campaigns in terms of Islamic religion. This was not surprising for the Freedom and Justice Party, which used slogans like "Islam is the solution" ${ }^{31}$ on banners and posters or the Party of Light, even when this was officially forbidden ${ }^{32}$. But also many secular parties framed their election campaigning events in religious terms, although they explicitly opposed raising religious slogans ${ }^{33}$. An interesting example is the Egyptian Bloc, which is led by the Party of the Free Egyptians, founded by the Coptic Naguib Sawiris ${ }^{34}$. The election campaign event of the Egyptian Bloc that was held in Mahalla al-Kubra on $9^{\text {th }}$ of December 2011 started with a Quran recitation from the Imam, which took around twenty minutes. After the Quran recitation the shabab al- 
thaura was praised and a minute's silence was made in commemoration of the martyrs of the revolution. Then the politicians held their speeches. After every speech a moderator was explaining how the speech was related to Islam. Also a Sheikh was holding a speech, in which he stated that the coalition is not anti-religious. Some speakers quoted newspaper articles of other Sheikhs and Imams who were emphasizing that it is not haram (religiously forbidden) to vote for the Egyptian Bloc ${ }^{35}$.

Competing with other religious parties that obviously had a lot of supporters the Egyptian Bloc tried to fix their reputation as "secular", but "Christian" party. They needed to show that especially Islam plays an outstanding role for them. By doing so they could also position themselves as party, which is following religious ideas, but might not be as "extreme" in their religious thinking as other parties.

It was a crucial question from many of my interview partners, if they as Muslims could vote for a secular party and was founded by a Christian. Several of my Muslim interview partners that voted for them because they were "in favour of a secular state" told me about their experiences in the polling stations in Cairo Downtown: Manal (31) stated: "I went to the polling station and asked the people outside and inside whom they are voting for. All of them answered: The Muslim Brotherhood. When I started to discuss with them and told them that I vote the Egyptian Bloc, they asked me, if I am not Muslim"36.

21 According to these examples, religion seemed to play an outstanding role in gaining acceptance from the people. Otherwise the Egyptian Bloc could just have outlined its idea of liberalism and secularism and there would not have been the need to render the whole event mainly in terms of Islamic religion. Also the reactions to Manal and the others would have been different. I want to stress that also many of my Muslim interview partners finally voted for the Egyptian Bloc, not necessarily because they were in favour of a secular state, but because they considered the prevalent religious political parties as too extreme concerning their religious ideas. Consequently, the mainly due to the Maspero-incident and the appearance of new Islamic collectives and parties - changing discourses on Islam deeply influenced the voting decision of my interview partners.

\section{Competitive claims from demonstrators during the parliamentary elections: Legitimate or illegitimate elections?}

On the $18^{\text {th }}$ November 2011, a few days before the first election round, demonstrations on Midan Tahrir and in other parts of Egypt began ${ }^{37}$. Two main demands seemed to dominate the demonstrations: The withdrawal of the controversial constitutional principles proposed by Deputy Prime Minister Ali El-Selmy ${ }^{38}$ and the handover of power of the SCAF to civilian rule no later than April $2012^{39}$. They culminated in violence mainly on Muhammad Mahmoud Street and led to a big number of people that intended to boycott the elections: "How do you want me to vote, when the parliament will have no powers if the military is still in charge?" said one of the protesters Mustafa Shaath $(30)^{40}$. The trust of people in the SCAF that had already suffered immensely due to its reactions on Maspero steadily decreased during the demonstrations, because of the violence against the demonstrator on Muhammad Mahmoud Street.

23 I was surprised that also many of my political active interview partners disqualified the protests on Tahrir. Heba (26), who is organizing public events for different political 
groups, just came back from talks with demonstrators on Muhammad Mahmoud Street, when she stated: "I do not understand what is going on at the moment. The people on Tahrir this is not shabab al-thaura. I think this is baltageya ("thugs"). This is not the revolution. We did our revolution in January. I am so confused. But we need the elections now ${ }^{41 "}$.

Menna (26), who witnessed from the AUC building the incidents on Muhammad Mahmoud Street, agreed with the protests. She said: "You know, most of my friends are supporting the Military Council. But after what happened in Muhammad Mahmoud I told them: If you do not understand what is going on at the moment, then we cannot be friends anymore. On Muhammad Mahmoud youth is fighting against the SCAF and they are better youth then you or me" ${ }^{42}$. She expressed that she considers the constitution is illegal and considered the Military council as not being the legitimate representative.

It is interesting to state that two different informants that talked to demonstrators on Muhammad Mahmoud labelled them in opposing ways: as the "real shabab al-thaura" and as the opposite from it, as baltageya. Also many of my other interview partners were using the signifier shabab al-thaura or baltageya to legitimize or delegitimize the protests.

The parties and the Military council had to react to these competing claims. They profoundly contested their role as current or future legitimate representatives. The parties suddenly did not only have to explain why they as a particular party would be good representatives compared to the other parties. They had to make a stand regarding the legal frame, the constitution and also to the revolution in order to show that their future role as representatives would be legitimated. By participating in the elections the parties and coalitions implicitly agreed on the legal frame and they were facing the problem, that they could have been considered as not real revolutionaries in the eyes of people.

\begin{tabular}{|l|l|}
\hline Parties (implicit claims) & Demonstrators (explicit claims) \\
\hline Recognizing the legal frame (constitution) & Not recognizing the legal frame (constitution) \\
\hline Military Council is the legitimate representative & Military council is not legitimate representative \\
\hline Elections will represent the people & Elections will not represent the people \\
\hline
\end{tabular}

It was particular difficult for the Completing the Revolution Alliance ${ }^{43}$ to react to the demonstrators. The Coalition was made up in October in order to bring the "Voices of Tahrir and the revolutionary Youth to the Parliament" ${ }^{44}$. So the coalition had to prove that they listen to the voices of the Tahrir that were mainly refusing the legal frame. At the same time it was still accepting the legal frame. Amr Hamzawy as the most prominent member of the coalition stopped his official election campaigning for a while in order to show his support for the demonstrations and then turned back to his campaign ${ }^{45}$. Stopping his campaign was part of his campaign.

The Muslim Brotherhood followed a different strategy: They avoided participating in the demonstrations on Midan Tahrir. In order to show that they are a kind of 
revolutionaries they made other demonstrations for the rights of the Palestinian people ${ }^{46}$.

Also the reaction of the Military council was interesting: On the one hand the Military council said during the uprisings in November, that it has to fight against the demonstrations in order to defend the election process. After the elections the SCAF said that the parliament in this way is not representative enough when it comes to write the constitution ${ }^{47}$.

It was not sure until the day of the elections, if they will take place at all. When 52\% from the eligible voters dropped their voice in the ballot box there was no discussion at all about the question, if the parliament could be declared as illegitimate due to the amendments of the law that the SCAF had agreed on due to the pressure of the parties and demonstrating groups. When the parliament was dissolved from the SCAF, it was not clear if the member of the parliaments would accept this decision and when the recently elected president Muhammad Mursi decided to hold a meeting in the parliament ${ }^{48}$ after its declared dissolve, it was completely unclear to the public how this meeting would end: As a counter-coup against the SCAF, declining the authority of the High Courts or/and simply as a presentation of his new gained power ${ }^{49}$.

\section{Conclusions}

31 By approaching the question of legitimacy from an empirical understanding, using claims and the acceptance of claims as an analytical tool, I aimed to demonstrate that legitimacy of political representation is not mainly the result of the static fact of elections - legitimacy could rather be understood as acceptance of people and groups, which is changing over time and can be institutionalized in different ways, depending on current political discourses.

The ways claims are brought forward depends on the prevalent discourses: A claim will be more successful when it refers to a certain argument or stream within a discourse that seems to have the support or the acceptance of most of the people and groups. Claims can be raised from "real" groups, like the Salafis. In fact, they became a collective by raising a claim and henceforth needed to be considered as a serious political player. But collectives can also be created through a discourse itself, like the fulul - none claimed to be a fulul. It is important to note that both groups (as well as the shabab al-thaura or the baltageya) are incorporated into a general discourse and became "discursive collectives" or "empty signifiers", through which the discourse changes. The fulul discourse enabled people to discuss what is good and bad for a society - the fulul as symbol for the old regime, associated with corruption and oppression versus the shabab al-thaura as symbol for freedom of expression and purity. The appearance of the Salafis as a collective changed the discourse about the role and the limits of Islam in politics. It was demonstrated how different parties referred to these discourses and how they used them to gain acceptance from the people. Raising claims is therefore not only a symbolical struggle of political groups in order to gain acceptance of the people - they change the ways people reflects on their society and consequently how they perceive themselves - this changes not only their decision whom to elect, what and whom to accept, but also influences their all-day routine in dealing with other people.

The example of the change in the election law clearly shows that claims can turn into fundamentally important political decisions concerning "legitimacy" itself, when the 
claim is supported through a discourse that most of the people seem to share, i.e. to accept. There might have been other strategic reasons for the political groups to demand the change of the election law, but by referring to the danger of the fulul, they could successfully enforce their claim. In comparison to most states of Europe, in Egypt institutions like the High Court and the institutions that decide over laws also have to raise claims in order to appear legitimate - they actively have to create the fiction of legitimacy. In Europe they only have to keep their status.

Focussing on the making of legitimacy from an empirical perspective seems very complex and challenging. In this paper I could provide only a few examples of how parties and groups frame their claims and how they were accepted or negotiated. One could question the representativeness of the given examples, chosen frames and groups. Other important considerations were not discussed, like the ways, how people gain their information that influences their opinions about claims.

However, important insights could be won: Firstly, the making of legitimacy turns out to be a highly sensitive, fluid and often paradoxical process. Secondly, by analysing how the discourses or frames of claims change, a deeper understanding of the political culture can be developed. As it is hard to foresee coming events, this understanding seems to be the only ground on which one can make sense of events. It is important to note, that discourses are also influencing the ways, how events are post-rationalized. The first weeks after the parliamentary elections the elections and procedures could be read as a story of success: High turnout of voters, apparently free and fair etc. This presented story of success completely ignores that the day before the elections none knew, if they will take place at all. Thirdly, every group or person, elected or not, can make claims, can gain acceptance and can therefore be political influential.

Using an empirical-driven approach entails a danger though: It makes it hard to set up normative standards to which the actual political system can be compared. On the other hand these normative standards were mainly developed in a certain context (mainly Europe) at a certain time in order to foster democratization, since the main question was: How should a democracy look like? Political and cultural conditions were incorporated in these normative theories without explicit reflection on it. In order to enable a more critical perspective on political systems, whether they are considered as democracies or not, theories on political representation now need to focus more on the practices of a state: Informal structures and persons and groups that might not have a position in the democratic system can be very influential even in "modern democracies".

\section{BIBLIOGRAPHY}

ABC News, 14.06.2012, Egyptian 'coup' dissolves parliament, http://abcnews.go.com/ International/egyptian-coup-dissolves-parliament/story?id=16569673\#.UD-kQ2VKGfI). 
Ahram Daily online, 01.10.2011, Egypt military rulers agree to amend election law, may lift emergency law, http://english.Ahram.org.eg/NewsContent/1/0/23093/Egypt/0/Egypt-militaryrulers-agree-to-amend-election-law,.aspx

- 01.11.2011, Reconstructing 's Bloody Sunday: An Ahram online investigation, http:// english.Ahram.org.eg/NewsContentPrint/1/0/25521/Egypt/0/Reconstructing-s-Bloody-SundayAn-Ahram-Onl.aspx

- 18.11.2011, Live Updates: Egypt's Friday of One Demand as it unfold, http:// english.Ahram.org.eg/News/26857.aspx

-20.11.2011, Several political figures and coalitions boycott campaigning after police crackdown in Tahrir, http://english.Ahram.org.eg/NewsContent/1/64/27051/Egypt/Politics-/Severalpolitical-figures-and-coalitions-boycott-c.aspx

Ahram weekly online, 12.-18.07.2012, Issue No. 1106, Inching towards a showdown?, http:// weekly.Ahram.org.eg/2012/1106/fr1.htm

- 13.-19.10.2011, Issue No. 1068, Political row over religious slogans, http:// weekly.Ahram.org.eg/2011/1068/eg51.htm

Aljazeera English, 14.06.2012, Egypt court orders dissolving of parliament, http:// www.aljazeera.com/news/middleeast/2012/06/2012614124538532758.html

Almasry Al-youm online, 06.11.2012, Elections campaigning played out in Eid, http:// www.almasryalyoum.com/en/node/512392

- 08.12.2012, Egypt's rulers: Parliament won't be representative, http:// www.almasryalyoum.com/en/node/539576

- 25.10.2011, The Revolution Continues Coalition hits the ground running, http:// www.almasryalyoum.com/en/node/508732

- 29.07.2011, Tahrir updates: 28 secular parties and coalitions pulling out from square, http:// www.almasryalyoum.com/en/node/481554

ANDERSON B., 2006, Imagined communities, London, Verso.

BBC News Middle East, 14.06.2012, In quotes: Egypt court rulings reaction, http://www.bbc.co.uk/ news/world-middle-east-18447398.

BJORNLUnd E., coWAN G. and GAllery W., 2007, 'Election Systems and Political Parties in Post-Conflict and Fragile States', in: Derick W. Brinkerhoff (ed.), Rebuilding Governance in Post-Conflict Societies and Fragile States: Emerging Perspectives, Actors, and Approaches, New York: Routledge.

Carnegie Endwoment for International Peace online, Download 02.11.2011, Istikmal al-Thawra, Completing the Revolution Alliance, http://egyptelections.carnegieendowment.org/2011/11/02/ istikmal-al-thawra-“completing-the-revolution"-alliance

- Download 07.09.2012, Al-Masriyeen al-Ahrrar, Free Egyptians Party, http://

egyptelections.carnegieendowment.org/2011/09/21/al-masriyeen-al-ahrrar-free-egyptiansparty.

Carter Center, 24.01.2012, Carter Center Election Witnessing Mission Egypt 2011/2012: Parliamentary Elections. Preliminary Report on all three phases of the people's assembly elections, http://www.cartercenter.org/resources/pdfs/news/peace_publications/ election_reports/Egypt-Peoples-Assembly-Elections.pdf 
Daily News Egypt online, 25.11.2011, Supporters of Al-Aqsa freedom gather at Azhar. http:// www.thedailynewsegypt.com/egypt/supporters-of-al-aqsa-freedom-gather-at-azhar.html.

Egypt Independent online, 02.08.2011, After show of force, Islamists debate role of religion in politics, http://www.almasryalyoum.com/en/node/482542

- 09.07.2012, Monday's papers: Morsy checkmates SCAF over Parliament, http:// www.egyptindependent.com/news/monday-s-papers-morsy-checkmates-scaf-over-parliament.

- 17.06.2012, SCAF expands its power with constitutional amendments, http://

www.egyptindependent.com/news/scaf-expands-its-power-constitutional-amendments.

- 17.06.2012, SCAF expands its power with constitutional amendments, http://

www.egyptindependent.com/news/scaf-expands-its-power-constitutional-amendments.

EL-MAHDI R., 11.04.2011, Orientalising the Egyptian Uprising, In: Jadaliyya online, http:// www.jadaliyya.com/pages/index/1214/orientalising-the-egyptian-uprising.

Emsekflol (www.emsekflol.com), 02.11.2011, Capture the Remnants: The Black List, http:// www.tahrirdocuments.org/2011/11/capture-the-remnants-the-black-list/.

Forbes online, 2010, The World's Billionaires: \#374 Naguib Sawiris, http://www.forbes.com/lists/ 2010/10/billionaires-2010_Naguib-Sawiris_4MRK.html.

International Foundation for Electoral Systems (IFES), 01.11.2011, Briefing Paper Elections in Egypt: Analysis of the 2011 Parliamentary Electoral System, http://www.ifes.org/ /media/Files/ Publications/White\%20PaperReport/2011/ Analysis_of_Egypts_2011_Parliamentary_Electoral_System.pdf.

Jadaliyya online, 16.11.2011, Egypt Elections Watch: Use with Caution, http://www.jadaliyya.com/ pages/index/3136/egyptian-elections-watch_use-with-caution.

LAClAU E. and MoufFE C., 1985, Hegemony and Socialist Strategy. Towards a Radical Democratic Politics, Great Britain, Verso.

MAIR P. and THOMASSEN J., 2010, 'Political representation and government in the European union', in: Journal of European Public Policy, Vol. 17, No. 1, pp. 20-35.

PITKIN H., 2004, 'Representation and democracy: uneasy alliance', in: Scandinavian Political Studies 27, No. 3, pp. 335-342.

REHFELD A., 2006, 'Towards a general theory of political representation', in: The Journal of Politics, Vol 68, $\mathrm{N}^{\circ} 1$, Cambridge University Press on behalf of the Southern Political Science Association, pp. 1-21.

Reuters online, 10.07.2012: Egypt's Islamist parliament reconvenes, defying army. http:// af.reuters.com/article/worldNews/idAFBRE8690CT20120710

- 09.10.2011, Egypt generals ban using religious slogans in vote, http://www.reuters.com/ article/2011/10/09/us-egypt-elections-idUSTRE79813420111009

SAWARD M., 2010, The representative claim, Oxford, New York, Oxford University Press. SCHWARTZ N. L., 1988, The blue guitar, Chicago, London, University of Chicago Press.

The daily news egypt online, 18.11.2011, Thousands rally in Tahrir on Friday of Protecting Democracy, http://www.thedailynewsegypt.com/egypt/thousands-rally-in-tahrir-on-friday-ofprotecting-democracy.html 
The Daily Star online, 02.10.2011, Egypt parties to review army vote concessions, http:// www.dailystar.com.lb/News/Middle-East/2011/Oct-02/150251-egypt-parties-to-review-armyvote-concessions.ashx\#axzz1ZYYSPfn1

The Egyptian Gazette online, 27.11.2011, Egypt braces for protests on eve of elections, http:// www.algomhuria.net.eg/egyptian_mail/m1/

WEBER M., 1980, Wirtschaft und Gesellschaft. Grundriss der verstehenden Soziologie, Tübingen: JCB Mohr.

\section{Law decrees}

Draft Declaration of the Fundamental Principles for the New Egyptian State, 01.11.2011, http:// www.constitutionnet.org/files/2011.11_-_constitutional_principles_document_english.pdf

Decree-Law 123, 2011, http://dl.dropbox.com/u/42683471/

IFES\%20Egypt\%20Briefing\%20Paper\%200ctober/SCAF\%20Decree\%20Law\%20123.pdf

\section{NOTES}

1. The provided data for this analysis are the result of a field research started in June 2011 and is still ongoing until December 2013. 200 semi-structured, in-depth interviews and discussions lasting from 15 minutes to three hours were conducted mainly in Cairo, Bahariya, Mahalla al-Kubra and Luxor. The interview partners are from various social layers (e.g. students, bedouins) and were chosen along criteria like educated/notedcuated, male/female, religious/not-religious, Copt/Muslim, city/countryside, supporter of the revolution/supporter of the old system etc.). With 15 fixed persons interviews were conducted several times during the research period. In the paper all names of interview partners are changed. The chosen quotes are representing narratives that appeared in different interviews several times.

2. The Democratic Coalition consisted of groups from different political parties as the Freedom and Justice Party and the liberal Wafd Party.

3. Supreme Council of the Armed Forces, Decree-Law 123/2011

4. like the Democratic Coalition and the Tagammu Party, see: International Foundation for Electoral Systems (IFES) 01.11.2011, p. 3

5. Ahram Daily online 1.10.2011, Egypt military rulers agree to amend election law

6. Ahram Weekly online 13.-10.10.2011, Political row over religious slogans

7. Carter Center 24.01.2012, p.1

8. Aljazeera English online 14.06.2012, Egypt court orders dissolving of parliament

9. Hossam Bahgat, a human rights activist, stated: "Egypt just witnessed the smoothest military coup. We'd be outraged if we weren't so exhausted". (See: BBC News Middle East online 14.06.2012, In quotes: Egypt court rulings reaction)

10. Hanna Pitkin, who was shaping and influencing theories on political representation over decades, stated in a speech on the occasion of her retirement as professor in 2004: "Like most people even today; I more or less equated democracy with representation or at least with representative government", 2004, p. 336.

11. Theories that equate political representation and democratic representation usually set up a list of normative criteria in order to assess the democratic stage a 
political systems is in, like free and fair elections, strong civil society, gender equality and so on. In fact this equation is a very modern phenomenon: "Only in the English Civil War and then in the eighteenth-century democratic revolutions did the two concepts become linked", Pitkin 2004, p. 335. The theories were developed mainly in Europe in a context of democratization and the main question that people were concerned with was: How should a democracy look like? Consequently, normative criteria to measure the democratization process were developed. The crisis of political representation theories then mainly occurred in a context in which more and more non-democratic representative institutions and NGOs appeared in the global field. (Rehfeld 2006, p. 1) Also the building of political supra-institutions within the European Union, which are criticized as not being representative due to the lack of electoral structures and for other reasons, strengthened the doubts about the normative approaches, since they did not include informal structures or the influence of notelected institutions and organizations. Mair 2010, p. 20-35, Especially the democratic elections of the Hamas in 2006, whose outcome was highly discussed and not accepted from different countries, Bjornlund 2007, p. 122, started a process of rethinking the meaning of legitimate political representation. I would also argue that a trigger for the slow turn from normative driven theories to empirical driven theories was the emerge of self-reflection about the meaning of cultural values, fostered by the discussions after the attacks on the $11^{\text {th }}$ September 2001 in New York and publications like Huntington's "Clash of Civilizations".

12. Saward defines a claim as follows: "Some individual or collective agent constructs or makes the claim - a 'maker'. And the thing represented is an idea of it, not the thing itself, which is better called a 'referent' (if the politician makes himself the 'subject' who stands for an 'object,' the object is his idea of his constituency rather than the referent, which is all the other things the constituency is, or might be). All of this needs, and has, an 'audience,' which receives the claims and accepts, rejects, or ignores them", 2010, p. 36.

13. Schwartz states, that "political representation can be conceived as an ongoing founding, as the constitution of community", stressing the idea that representation has to be understood as set of practices and events, and not as "making something present" as many theorists have asserted, 1988, p. 53.

14. Rehfeld 2006, p. 2

15. Saward 2010, p. 2

16. Following Max Weber acceptance in this context is understood as 'will to obey' "Gehorchen wollen", see: Weber 1980, p. 122

17. Jadaliyya online 16.11.2011, Egypt Elections Watch: Use with Caution, p. 3

18. Jadaliyya online 16.11.2011, Egypt Elections Watch: Use with Caution, p. 3

19. Forbes online 03.10.2010, The World's Billionaires: \#374 Naguib Sawiris

20. Own observations

21. www.emsekflol.com: Youth of 6 April, the Movement to Apprehend the Remnants, the Alliance of Youth of the Revolution, the Movement of Youth for Justice and Freedom, the National Center of Popular Councils; see: Tahrir Documents 02.11.2011, Capture the Remnants: The Black List.

22. Interview conducted on the 19.11.2011 in the museum of Anwar Sadat, Mit Abu alKum, Nile Delta 
23. A very strong tool from the parties to present themselves a anti-fulul was to claim to represent the shabab al thaura, the youth of the revolution, which is considered as the driving force of the revolution and therefore as being good and pure. Every party stated to have shabab al-thaura amongst their members. This strategy allowed them to incorporate the positive values the shabab al-thaura was associated with.

24. The Daily Star online 02.10.2011, Egypt parties to review army vote concessions

25. International Foundation for Electoral Systems (IFES) 01.11.2011, p. 3

26. Egypt Independent online 17.06.2012, SCAF expands its power with constitutional amendments

27. Al-Masry al-Youm online 29.07.2011, Tahrir updates: 28 secular parties and coalitions pulling out from square, and: Egypt Independent online 02.08.2011, After show of force, Islamists debate role of religion in politics

28. Several of my informants made exactly the same statement.

29. El-Mahdi, 11.4.2011, Orientalising the Egyptian Uprising

30. Also see: Ahram Daily online 01.11.2011, Reconstructing 's Bloody Sunday: al-Ahram online investigation

31. Al-Masry al-Youm , 06.11.2012, Elections campaigning played out in Eid

32. Reuters 09.10.2011, Egypt generals ban using religious slogans in vote

33. Ahram Weekly online 13.-10.10.2011, Political row over religious slogans

34. Carnegie Endowment for International Peace 21.09.2011, Al-Masriyeen al-Ahrrar, Free Egyptians Party

35. Own observations

36. The interview was conducted at the first day of the parliamentary elections, 28.11.2011, in front of a polling station in Downtown, Cairo.

37. Ahram Daily online18.11.2011, Live Updates: Egypt's 'Friday of One Demand' as it unfold

38. Draft Declaration of the Fundamental Principles for the New Egyptian State, 11.2011

39. Daily News Egypt online18.11.2011, Thousands rally in Tahrir on Friday of 'Protecting Democracy'

40. The Egyptian Gazette online 27.11.2011, Egypt braces for protests on eve of elections

41. Interview was conducted in the afternoon of the 24.11.2011, near Midan al-Tahrir

42. Interview was conducted in the morning of the 24.11.2011, Zamalek

43. Carnegie Endowment for International Peace online 02.11.2011, Istikmal al-Thawra, Completing the Revolution Alliance

44. Al-Masry al-Youm online 25.10.2011, The Revolution Continues Coalition hits the ground running

45. Ahram online 20.11.2011, Several political figures and coalitions boycott campaigning after police crackdown in Tahrir

46. The Daily News Egypt online 25.11.2011, Supporters of Al-Aqsa freedom gather at Azhar

47. Al-Masry al-Youm online 08.12.2012, Egypt's rulers: Parliament won't be representative 
48. Egypt Independent online 09.07.2012, Monday's papers: Morsy checkmates SCAF over Parliament

49. Ahram Weekly online 12.-18.06.2012, Inching towards a showdown?

\section{ABSTRACTS}

In times of transformation and extreme fluidity in which the sources of legitimate political representation like elections, constitutions etc. are contested, alternative theoretical understandings of political representation and legitimacy need to be developed in order to explain change. Starting from the assumption that elections are only a snapshot that show acceptance at a certain moment, the article explores the making and the reception of claims during the parliamentary elections 2011/12 in Egypt. The following questions are raised: How can we think about legitimate political representation for a better understanding of the transformation process in Egypt? How can we explain the changes and developments concerning political representation during the parliamentary elections 2011? The provided data are the result of a field research started in December 2010 containing in-depth interviews with a wide range of actors.

À une époque de grandes transformations durant lesquelles les sources habituelles de légitimité telles que les élections, les constitutions, etc. sont contestées, le besoin se fait sentir de développer de nouvelles théories de la représentation politique et de la légitimité pour comprendre et expliquer le changement. Partant du postulat que les élections ne sont qu'un instantané montrant ce qui est accepté à un moment donné, cet article s'intéresse à la formulation et à la réception des revendications pendant les élections législatives égyptiennes de 2011-2012. Les questions suivantes sont examinées: Comment pouvons-nous penser la représentation politique légitime afin de mieux comprendre le processus de transformation en cours en Égypte? Comment expliquer les changements et les développements concernant la représentation politique durant ces élections? Les données examinées ont été recueillies durant un travail de terrain débuté en décembre 2010, au cours duquel nous avons réalisé des entretiens approfondis avec une grande variété d'acteurs.

\section{INDEX}

Keywords: Legitimacy, Claims, Political Representation, Political Culture, Revolution

Mots-clés: légitimité, revendications, représentations politiques, culture politique, révolution

\section{AUTHOR}

\section{SARAH WESSEL}

Sarah Wessel, born 1981 in Speyer, Germany; 2003-2009 Study and graduation in Social Anthropology, Islamic Studies and Political Science at the University of Muenster (Germany); 2005/06 Study and research in Egypt; 2009 Master Thesis on: “The representation of the Egyptian 
Economy in German Newspapers - an Ethnological Analysis"; Since $2010 \mathrm{PhD}$ student at the University of Hamburg in Political Science; Since June/2011 in Egypt for field work; Associated to the Cairo University; Current title of the PhD: "Political Representation and Legitimacy in Postrevolutionary Egypt".

Sarah Wessel, née en 1981 en Allemagne, prépare une thèse d'anthropologie culturelle à l'université de Hambourg. Elle vit en Égypte depuis décembre 2010 pour réaliser son travail de terrain, dans le cadre de son étude portant sur : «La construction de la légitimité dans l'Égypte post-révolutionnaire : une approche des représentations "par le bas" " 